\title{
Interrelationships among ecological factors of brachyuran crabs, trees and soil in mangrove community assemblage in Northeast Brazil
}

\author{
A. C. Ferreira' ${ }^{1,3}$, C. E. R. D. Alencar ${ }^{2}$ and L. E. A. Bezerra ${ }^{1}$ \\ ${ }^{1}$ Marine Sciences Institute (LABOMAR), Federal University of Ceará (UFC) - 3207 Abolição Ave, 60165-081, \\ Fortaleza, Ceará, Brazil \\ ${ }^{2}$ Study Group in Ecology and Physiology of Aquatic Animals (GEFAA), Federal University of Rio Grande do Norte - \\ w/n Mor Gouveia Ave, 59078-970, Natal, Rio Grande do Norte, Brazil \\ ${ }^{3}$ Corresponding author. E-mail: alexcrab90@hotmail.com
}

Keywords: Crab communal burrows; Ecosystem engineer; Goniopsis cruentata; Key faunal group; Neotropical mangrove; Rhizophora mangle.

\begin{abstract}
Mangroves are dynamic ecosystems due to influence of abiotic and biotic factors, but the latter are far less studied. Interactions between key invertebrate groups, trees, and soil properties, among others, determine the community structure throughout mangrove stand developing. Covariation among these factors, however, obscures their mutual relationships in shaping mangrove community assemblage patterns. In the estuary of Pacoti River (Ceará State, northeast Brazil), we compared the diversity and distribution of brachyurans and trees among several mid-littoral areas, and their relation with sediment features, to understand their relationships in community assemblage of new mangrove stands in developing. To discriminate the relation among these variables, ordination of data (PCA) and multivariate multiple correlation (PLS) were used. Data show that intertidal establishment of Brachyura was determined primarily by sediment properties, but further spatial distribution and diversity of this key faunal group, and the tree species that establishes, can influence each other. The prop roots habitat of Rhizophora mangle supports a higher brachyuran richness, since it allows the existence of multispecific crab burrow systems underground. Our results show that Rhizophora and brachyurans are key engineer organisms involved in shaping the physical and, hence, the ecological structure of newly established mangrove stands at Neotropics.
\end{abstract}

Abbreviations: A - Avicennia germinans area; $\mathrm{R}$ - Rhizophora mangle area; $\mathrm{L}$ - Laguncularia racemosa area; $\mathrm{RL}$ - Rhizophora + Laguncularia area; AL - Avicennia + Laguncularia area; RLA - Rhizophora + Laguncularia + Avicennia area; C - Control area; Pen - Sediment penetrability; S - sediment salinity; OM - organic matter; $\mathrm{Cl}+\mathrm{Sl}$ - clay + silt; TDiv - Tree diversity; Dom - Tree dominance; SeeDens - Seedling density; TDens - Tree density; TM/J - rate of mature trees; CrbRich - Crab richness; Gon - abundance of Goniopsis cruentata; UBurr - abundance of Ocypodoidea crabs; SnDiv - Snail diversity; PCA - Principal Component Analyses; Var - Proportion of variance; CumVar - Cumulative variance; PLS - Partial Least Squares; VIP - Variable Importance Projection; PLSw - Weight of variable; PLSv - Proportion of variance.

Nomenclature: Graham (1995) for plants; Ng et al (2008) and Shih et al (2016) for crabs.

\section{Introduction}

Mangroves are highly productive biological communities that have been decreasing in extension in the last decades (Valiela et al. 2001, Lacerda 2002, Worthington and Spalding 2018). These forests are associated with river deltas and sheltered coasts, where the trees are salt stress tolerant inhabitants of littoral tidal soils. Mangrove stands change in response to the dynamic estuarine environment, which is continuously building and modifying landforms through several abiotic and biotic factors. Abiotic factors include rain, winds, tidal flooding, sea level, and sediment features (Thom 1967, Cintrón and Schaeffer-Novelli 1983, Woodroffe 1983, Clarke and Allaway 1993, Krauss et al. 2008). Biotic factors include tree architecture (with tree species determined by competition for light and seed herbivory, among others), soil bioturbation and plant-soil interactions driven by sediment microbiota, most notably by benthic fauna engineering (Warren and
Underwood 1986, Lee 1999, Minchinton 2001, Cannicci et al. 2008, Ferreira et al. 2013, 2019).

The composition of macrobenthic communities in terms of species richness and abundance can significantly influence forest ecological processes dependent of soil, like settlement, development and productivity (Smith et al. 1991, Morrisey et al. 2003, Chapman and Tolhurst 2004, Kristensen and Alongi 2006). Brachyuran crabs, mainly from the superfamilies Ocypodoidea and Grapsoidea (Brachyura: Decapoda) (Ng et al. 2008) are among the most abundant and ecologically significant components of mangrove food webs (Koch and Wolff 2002). These brachyurans form a key group of ecosystem engineers and play a significant role in the composition (grain size, chemistry) and topography of sediment due to their fossorial activity (Warren and Underwood 1986, Jones et al. 1994, Kristensen 2008; Quintero-Torres et al. 2018). They also influence forest development and structure, since through selective propagule consumption they can decrease 
recruitment of some tree species, favoring others (Smith III 1987a,b, Ferreira et al. 2013).

Mutually, sediment features (highly influenced by tidal regime) appear as significant determinants of brachyuran distribution and abundance from early stages, since planktonic larvae search an appropriate littoral substrate to settle and dig burrows (Butman 1987, Zenone et al. 2016). Likewise, specific trees, in particular their root architecture, also influence crab diversity and distribution (Macintosh et al. 2002, Ashton et al. 2003b, Tews et al. 2004, Kristensen and Kostka 2005, Ferreira et al. 2015, Leung et al. 2015a,b). Hence, crab assembly structure can differ between early stages of mangroves in relation to microhabitat and sediment characteristics (Aschenbroich et al. 2016), also considering changes induced by fast sea level rise. So, how ecological factors related to crabs, trees and sediment co-operate in community assemblage at initial stages of forest development? How brachyuran diversity and spatial niche respond to, and influence upon, forest features related to tree richness, density and architecture? To gain insight about these processes it is necessary to describe and discriminate the role of such factors since young mangrove stand settlement. For this purpose, we used novel techniques of multivariate statistics, which can help to explore data and shed light on stated questions.

In Northeastern semiarid region of Brazil, estuaries like the Pacoti (Ceará State) are suffering accelerated physiographic changes due to increasing ocean level, extreme droughts and heavy rains, and human intervention like damming and cattle breeding (Ferreira and Lacerda 2016). This raises the concern on how these changes can affect the mangrove biodiversity patterns and threatens habitat of species at risk (e.g., Ucides cordatus, Cardisoma gunahumi - Goes et al. 2010, Carmona-Suarez 2011). Since brachyurans can be used as indicators of the reestablishment of some ecosystem functionalities (Chen et al. 2007, Feng et al. 2014, Ferreira et al. 2015), this study can improve conservation and rehabilitation policies of mangroves.

\section{Methods}

Study area

Pacoti river is located in the metropolitan region of the city of Fortaleza, state of Ceará (northeast Brazil) ( $3^{\circ} 48^{\prime}$ $3^{\circ} 52^{\prime} \mathrm{S} / 38^{\circ} 24^{\prime}-38^{\circ} 26^{\prime} \mathrm{W}-$ Fig. 1). Climate is tropical with annual mean temperature between $25^{\circ} \mathrm{C}$ and $27^{\circ} \mathrm{C}$. Average annual rainfall is below $875 \mathrm{~mm}$ (Barreto et al. 2012), reaching up to $1,200 \mathrm{~mm}$ in the coast, mainly from February to June (wet season). Until the early 1980s, the estuary harbored salt production ponds, established over the original mangroves in the 1960s, but most ponds are deactivated today. The coastal basin, downstream from the last artificial reservoir, covers an area of approximately $132 \mathrm{~km}^{2}$. Tides are semidiurnal with maximum tidal amplitude of about $3.1 \mathrm{~m}$ and a minimum of $0.9 \mathrm{~m}$.

Estuarine littoral areas of the Pacoti are currently subjected to great changes due to the influence of the rising ocean level and human factors, such as dam construction upstream (Lacerda and Marins 2002, Lacerda et al. 2007). While some mangrove patches have disappeared, others are currently expanding, mostly in newly formed sediment areas and deactivated shrimp and saline ponds. Rhizophora mangle, Laguncularia racemosa, and Avicennia germinans are the predominant species.

\section{Sampling strategy}

Littoral areas in this study were selected to explore the interrelation between diversity of brachyuran assemblage, tree species (multiple and monospecific stands), and sediment features in the Pacoti mangrove forest development. Initial survey indicated that Pacoti estuary presented a conspicuous scenario of different ecophysiography and interaction between criteria previously mentioned. Hence, seven natural areas separated by at least $200 \mathrm{~m}$ were selected in the lower

Figure 1. The Pacoti river estuary in the state of Ceará, Brazil. The right image shows the river at their left, surrounded by mangroves, until the discharge in the Atlantic Ocean at the top; part of forest areas in the center of the image are semi-deciduous seasonal coastal forest, and the white areas on the left are dune formations. Sampled areas are indicated with black points and letters indicate mangrove trees (see text for details).

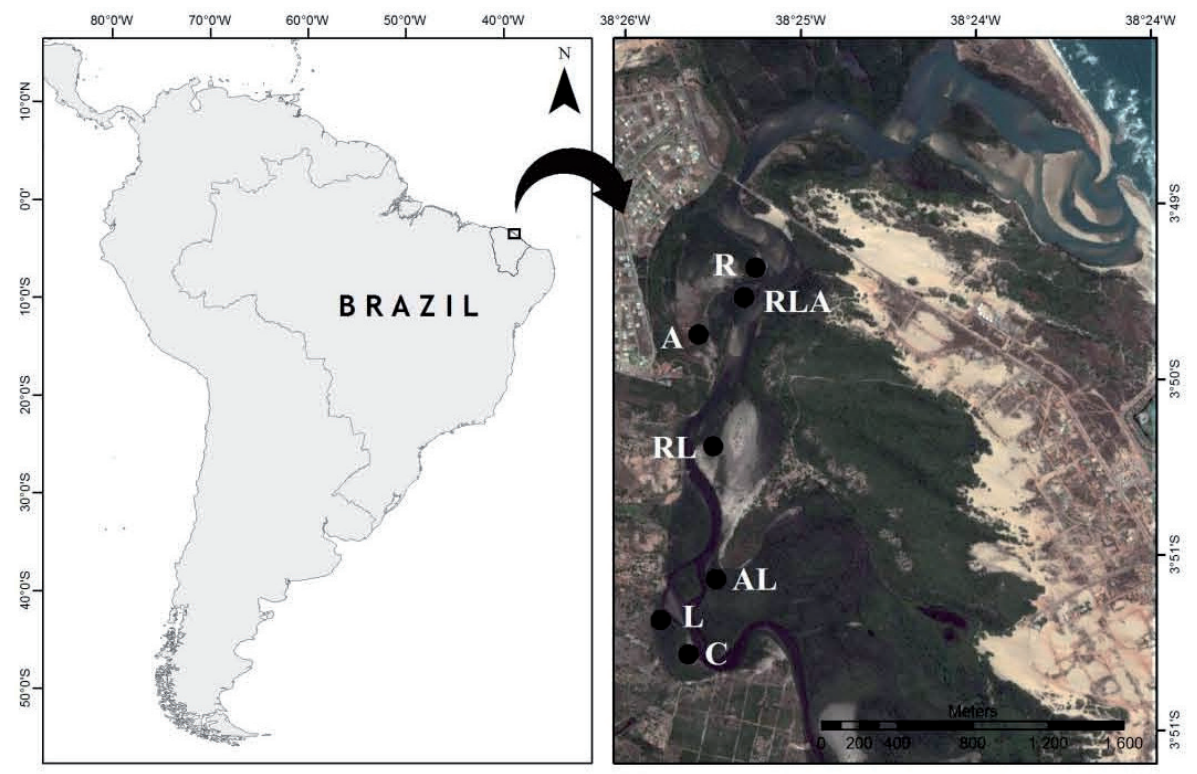


portion of the Pacoti estuary (Fiuza et al. 2010). The areas have young mangroves ( $\leq 3$ years old) in development (from seedlings to a maximum height of $4.5 \mathrm{~m}$ ), and different monospecific and multispecific tree compositions (Fig 1). The monospecific areas of $R$. mangle, L. racemosa, and A. germinans (from now on referred to only by the generic names) will be called R, L, and A respectively. The mixtures of different species were named with their corresponding letters (RL, AL, and RLA). The RA mixture was not found. A control area (C) without mangrove vegetation was also surveyed. Some patches of mangrove vegetation in Pacoti estuary had not similar sites for replication in the design proposed here. Also, several potential sites were disturbed by human occupation and therefore beyond the scope of the present study. Then we considered each mangrove vegetation patch surveyed as a representative unit, assuming that the sampled patches represent different stages of a mangrove development continuum at the estuary (Pickett 1989, Fukami and Wardle 2005, Chen et al. 2007, Alongi 2009, Leung 2015b).

1. Forest characterization. All samples were taken at spring low tide, at the beginning of the wet season. We used a quadrat of $5 \mathrm{~m} \times 5 \mathrm{~m}$ (Schaeffer-Novelli and Cintrón 1986) to survey the following parameters, or variables, in each area: (1) tree diversity (TDiv) (Shannon index), (2) tree dominance (Dom) (Simpson's index) (Brower and Zar 1994), plant density by square meter, one measure (3) considering only seedlings (SeeDens) and another (4) counting all individuals from sapling stage to higher sizes (TDens), and (5) forest maturity $(\mathrm{TM} / \mathrm{J})$, such as the rate of mature trees $(\geq 1.8 \mathrm{~m}) /$ juvenile $(<1.8 \mathrm{~m})$ (Ferreira et al. 2015) which means more open space between trees, oppositely to TDens. Seedling density measurements were systematized using a numerical code: 0 , no seedlings; $1, \leq 30 ; 2,31-60 ; 3,>60$ seedlings per square meter. The size of some forest patches, such as in RLA area, limited the survey to a single quadrat, and we standardized this procedure to all sites. We applied specific statistical analysis taking into account this problem (see Data analyses section).

2. Brachyuran surveys. In the same quadrats of forest characterization, prior to brachyuran collection we 1) estimated the abundance of grapsoid crab Goniopsis cruentata (from now on referred to only by the genus) as a number of adult individuals (nearly $\geq 3 \mathrm{~cm}$ carapace width) per square meter, counting individuals at $\leq 10 \mathrm{~m}$ distance of plots (Ferreira et al. 2013). This wandering species is significant because of its predatory-herbivorous habits, broad ecological niche, and influence on mangrove forest structure (Ferreira et al. 2013). In the quadrats, the abundance of ocypodoids (UBurr) (2) was estimated as the number of fiddler crabs (i.e., several genera previously grouped under genus " $U c a$ " spp. - Shih et al. 2016) and Ucides burrows per square meter, being the latter in general two orders of magnitude less abundant. Ocypodoid species inhabit individual burrows and are easily identifiable by size like Ucides cordatus (from now on referred to only by the genus), or external activity like fiddler crabs. Brachyuran species were collected in the quadrats at the surface and by excavating burrows whenever the roots allowed, by one collector in one hour, and after were 3 ) identified and counted (CrbRch). We checked the presence of systems of communal burrows of crabs (Ferreira and Sankarankutty 2002), which are recognizable in general by multi-opened entrances constructed in mangrove sediment surface. We also 4) surveyed snail (Gastropoda, Mollusca) diversity (SnDiv) (Shannon index) to explore their role on mangrove community structure (Smith III et al. 1989, Proffitt and Devlin 2005).

3. Soil features. Mangrove 'soil' is composed of sediments, but the use of term soil is extended (Lacerda et al. 1995, Donato et al. 2011, Alongi 2014, Kauffman et al. 2018) and we will use for practical purposes. The following soil features were measured and averaged from five randomly selected replicate sub-plots of $1 \mathrm{~m} \times 1 \mathrm{~m}$ in each $5 \mathrm{~m} \times 5 \mathrm{~m}$ plot: (1) penetrability (Pen) (i.e., substrate softness), (2) salinity (S), (3) percentage of organic matter (OM), and (4) percentage of clay+silt $(\mathrm{Cl}+\mathrm{Sl})$. Soil penetrability was measured by vertically releasing a centimeter-graded steel rod $45 \mathrm{~cm}$ long, 1.3 $\mathrm{cm}$ in diameter and $370 \mathrm{~g}$ in weight, from a height of $1.2 \mathrm{~m}$ (Ferreira et al. 2013). Salinity was measured in water samples extracted $15 \mathrm{~cm}$ deep in the sediment using an optical refractometer. Soil samples were collected from each site using a soil core sampler $(30 \mathrm{~cm}$ long and $10 \mathrm{~cm}$ in diameter). At the laboratory, a fraction of sediment was used to determine the organic matter content using the method of weight loss on ignition (Schulte and Hopkins 1996). Other sample of sediment was sieved to separate the sand from the clay+silt fraction (see Methodologies in Colares and Melo 2013).

In an area of mature $R$. mangle forest at the estuary, during a spring low tide, we injected polyurethane expansible foam into communal burrows between roots to extract casts of these systems. The material expands after applied and does not harm the environment since it was extracted soon after solidifying. The sediment around the cast was carefully removed at low tide to release the form. We present here the most complete cast, since several others were extracted incomplete.

\section{Data analyses}

The ecological variables of soil, tree and crab assemblage were explored to discover the significance of their influence, or 'weight', in community shaping. The variables crab richness, abundance of Goniopsis, and abundance of ocypodoid crabs (respectively CrbRch, Gon and UBurr) represent the 'brachyuran diversity'.

First, data were standardized by $\mathrm{z}$-score procedure (Gotelli and Ellison 2004), inspected for the presence of outliers by means of a Cleveland dot plot (Cleveland 1993) for each variable separately, and ordinated using a correlationbased principal component analysis (PCA) to explore their relationships, considering the principal components with at least $70 \%$ explained cumulative variation. PCA is relevant to interpret data variations without taking the sample classifiers into account and to obtain data variation without betweenand within-variation (Joliffe 2002).

Secondly, ecological variables were also analyzed using the multivariate Partial Least Square (PLS) regression technique, which generalizes and combines principal component 
Table 1. Brachyura and Gastropoda species collected at Pacoti River. Areas are indicated as R (R. mangle), L (L. racemosa), A (A. germinans) and mixed (RL, AL, and RLA). Crab Superfamilies ( $\mathrm{Ng}$ et al. 2008) are indicated (grapsoids, ocypodoids, and xanthoids). Asterisks $(*)$ indicate the presence of communal burrows.

\begin{tabular}{|c|c|c|c|c|}
\hline \multirow[t]{2}{*}{ Area } & \multicolumn{3}{|c|}{ Crab species } & \multirow[t]{2}{*}{ Snail species } \\
\hline & Grapsoids & Ocypodoids & Xanthoids & \\
\hline A & Sesarma rectum & Мinиса rapax & & $\begin{array}{l}\text { Littoraria angulifera } \\
\text { L. flava }\end{array}$ \\
\hline $\mathrm{R}^{*}$ & $\begin{array}{l}\text { Goniopsis cruentata } \\
\text { Aratus pisonii } \\
\text { Sesarma curacaoense }\end{array}$ & $\begin{array}{l}\text { Leptuca cumulanta } \\
\text { Minuca thayeri } \\
\text { Ucides cordatus }\end{array}$ & $\begin{array}{l}\text { Eurytium } \\
\text { limosum }\end{array}$ & $\begin{array}{l}\text { Littoraria angulifera } \\
\text { Melampus coffeus }\end{array}$ \\
\hline $\mathrm{L}$ & $\begin{array}{l}\text { Goniopsis cruentata } \\
\text { Aratus pisonii } \\
\text { Sesarma curacaoense } \\
\text { Pachygrapsus gracilis }\end{array}$ & $\begin{array}{l}\text { Leptuca cumulanta } \\
\text { Minuca thayeri }\end{array}$ & $\begin{array}{l}\text { Eurytium } \\
\text { limosum }\end{array}$ & Littoraria angulifera \\
\hline $\mathrm{RL}^{*}$ & $\begin{array}{l}\text { Goniopsis cruentata } \\
\text { Aratus pisonii } \\
\text { Sesarma curacaoense } \\
\text { Pachygrapsus gracilis }\end{array}$ & $\begin{array}{l}\text { Leptuca cumulanta } \\
\text { Minuca thayeri } \\
\text { Ucides cordatus }\end{array}$ & $\begin{array}{l}\text { Eurytium } \\
\text { limosum }\end{array}$ & $\begin{array}{l}\text { Littoraria angulifera } \\
\text { Melampus coffeus }\end{array}$ \\
\hline $\mathrm{AL}$ & $\begin{array}{l}\text { Goniopsis cruentata } \\
\text { Sesarma rectum } \\
\text { Pachygrapsus gracilis }\end{array}$ & Minuca rapax & $\begin{array}{l}\text { Eurytium } \\
\text { limosum }\end{array}$ & Littoraria angulifera \\
\hline RLA* & $\begin{array}{l}\text { Goniopsis cruentata } \\
\text { Aratus pisonii } \\
\text { Sesarma rectum }\end{array}$ & $\begin{array}{l}\text { Leptuca cumulanta } \\
\text { Minuca rapax } \\
\text { Ucides cordatus }\end{array}$ & & $\begin{array}{l}\text { Littoraria angulifera } \\
\text { Melampus coffeus }\end{array}$ \\
\hline $\mathrm{C}$ & & $\begin{array}{l}\text { Uca maracoani } \\
\text { Leptuca leptodactyla }\end{array}$ & & Neritina virginea \\
\hline
\end{tabular}

analysis and multiple regression characteristics. This technique is ideal for modeling situations when we have several variables but not necessarily many samples or observations (Höskuldsson 1988). Also, using PLS avoid collinearity and achieve normality of the data matrix are not necessary (Sobek et al. 2005). Here, PLS was used to estimate a set of dependent variables, i.e., brachyuran richness, density of Goniopsis and fiddler crabs, and snail diversity ("fauna matrix") from a set of independent variables of sediment ("soil matrix"), mangrove trees ("flora matrix"), and a mix of soil and mangrove trees ("environmental matrix") (see Abdi 2007). Moreover, we compared flora and soil matrices considering soil as an independent variable. PLS regression generates a statistic, the variable importance projection (VIP), which shows the contribution of the independent variables to the community assembly model. VIP values greater than 1 are considered as a high variable contribution to the model, values between 0.8 and 1 are considered a relevant contribution, and values below 0.8 are not relevant to the model (Wold 1995, Vale et al. 2017). Independent variable weights were used to determine their influence on the projection (VIP). For each PLS model generated (Soil vs. Fauna, Flora vs. Fauna, Environment vs. Fauna, Soil vs. Flora), the variable importance projection (VIP) and weights of the independent variables from the first two relevant variance explained PLS axes were inspected. The PLS analysis is already used to explore several ecological aspects (Nash et al. 2005, Sobek and Tranvik 2005, Vale et al. 2017).

Data were inspected, treated, and subjected to principal component analysis using PAST software (Hammer et al. 2001). PLS regression was performed using $R$ software (R Development Core Team 2012) and the 'plspm' package (Sanchez \& Trinchera 2012).

\section{Results}

Twelve crab species (five grapsoids, six ocypodoids, and one xanthoid) and four snail species were collected from the surveyed intertidal mangrove areas (Table 1). Areas R, RL, and $\mathrm{L}$ were the richest in brachyuran species, and communal burrow systems were found in R, RL, and RLA formations. The burrow system cast obtained (approximate dimensions: max. vertical axis $25 \mathrm{~cm} /$ max. horizontal axis $60 \mathrm{~cm}$.) (Fig. 3 ) shows multiple openings of different diameter to soil surface, leading to a large main chamber with interconnecting tunnels of varied diameters at different levels. Fiddler crabs burrows are in general not part of the systems. In some portions of the system, the foam solidified and stopped before reach their whole tunnels extension, so some inferior tunnels may be longer, and, since some portions of the cast corresponding to small tunnels broke when extracted, they can be more branched.

The PCA and PLS plots of analysis are shown in Figure 2 for the measured soil, plant, and fauna variables in each area (Table 2). Three principal components (PCs) of PCA explained $70.42 \%$ of the total data variation (Table 3 ), showing relevant associations between abiotic and biotic variables and the areas (Fig. 2a, b). PCs 1 and 2 (Fig. 2a) showed a strong positive association between $\mathrm{R}$ and $\mathrm{RL}$ areas with the 'brachyuran diversity' variables (CrbRch, Gon, and UBurr), 
Table 2. Soil, plant and faunal ecological variables at sampled areas in the Pacoti estuary. Values of soil parameters are averaged. Areas are indicated as R (R. mangle), L (L. racemosa), A (A. germinans) and mixed (LA, RL, and RLA). Asterisks $\left(^{*}\right)$ indicate the presence of communal burrows. Areas with mixed young $R$. mangle and A. germinans were not found. Soil variables: Pen, soil softness; $\mathrm{S}$, salinity; OM, organic matter content; $\mathrm{Cl}+\mathrm{Sl}$, clay + silt or fine sediment content; Plant variables: TDiv, tree diversity; Dom, tree dominance; SeeDens, seedling density; TDens, tree density; TM/J, forest maturity; Fauna variables: CrbRch, crab richness; Gon, number of subadult-adults of Goniopsis; UBurr, Ocypodoidea crabs burrows; SnDiv, snail diversity. Variables Gon, CrbRich and UBurr were grouped as 'brachyuran diversity'.

\begin{tabular}{lcccccccccccccc}
\hline & \multicolumn{3}{c}{ Soil } & \multicolumn{1}{c}{ Plant } & \multicolumn{3}{c}{ Fauna } \\
\hline Area & $\begin{array}{c}\text { Pen } \\
(\mathrm{cm})\end{array}$ & $\begin{array}{c}\mathrm{S} \\
(\mathrm{ppt})\end{array}$ & $\begin{array}{c}\mathrm{OM} \\
(\%)\end{array}$ & $\begin{array}{c}\mathrm{Cl}+\mathrm{Sl} \\
(\%)\end{array}$ & TDiv & Dom & $\begin{array}{c}\text { SeeDens } \\
\left(\mathrm{m}^{2}\right)\end{array}$ & $\begin{array}{c}\text { TDens } \\
\left(\mathrm{m}^{2}\right)\end{array}$ & $\begin{array}{c}\mathrm{TM} / \mathrm{J} \\
\text { CrbRch }\end{array}$ & $\begin{array}{c}\text { Gon } \\
\left(\mathrm{m}^{2}\right)\end{array}$ & $\begin{array}{c}\text { UBurr } \\
\left(\mathrm{m}^{2}\right)\end{array}$ & SnDiv \\
\hline A & 10.9 & 60 & 5.56 & 22.68 & 0 & 1 & 0 & 1.96 & 0.633 & 2 & 0 & 78.4 & 0.686 \\
$\mathrm{~L}$ & 17.2 & 39 & 2.88 & 20.39 & 0 & 1 & 3 & 4 & 0.666 & 7 & 0.12 & 226.4 & 0 \\
$\mathrm{R}^{*}$ & 19.9 & 43 & 7.73 & 41.49 & 0 & 1 & 0 & 3.6 & 0.126 & 7 & 0.32 & 169.6 & 0.686 \\
RL* & 13.7 & 37 & 8.91 & 42.34 & 0.333 & 0.812 & 1 & 12.28 & 0.085 & 8 & 0.28 & 421.6 & 0.124 \\
AL & 10.8 & 30 & 9.22 & 49.99 & 0.255 & 0.866 & 1 & 3.92 & 0.96 & 5 & 0.2 & 102.4 & 0 \\
RLA* & 6.2 & 40 & 2.35 & 14.26 & 0.935 & 0.446 & 2 & 7.72 & 0.199 & 6 & 0.32 & 57.6 & 0.358 \\
C & 7.4 & 37 & 3.11 & 21.98 & 0 & 0 & 0 & 0 & 0 & 2 & 0 & 193.6 & 0 \\
\hline
\end{tabular}
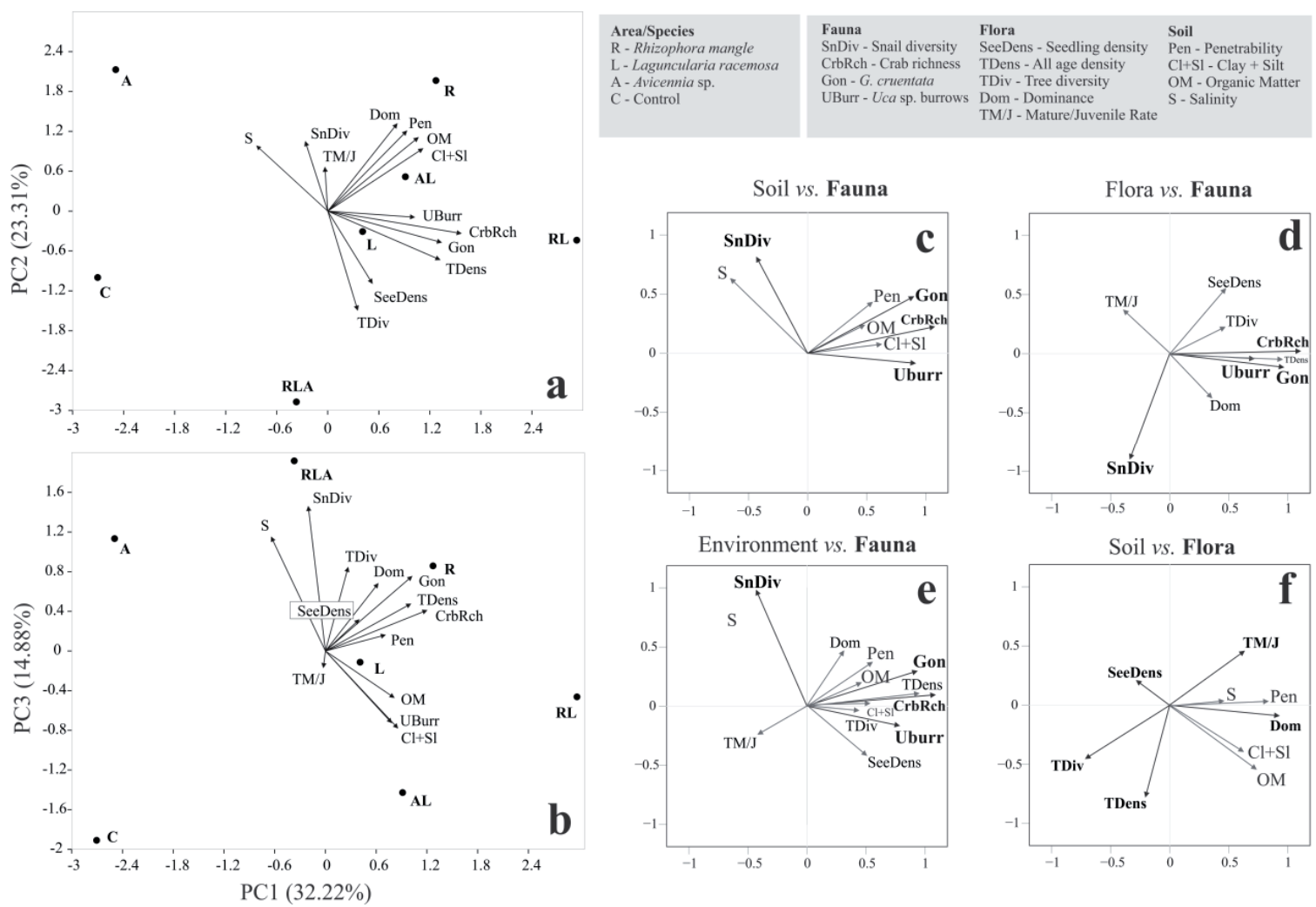

Figure 2. Biplots of Principal Components Analysis: PC1 vs. PC2 (a) and PC1 vs. PC3 (b) of abiotic and biotic variables collected in monospecific (A, R, L), multispecific (AL, RL, RLA) and Control (C) areas at the Pacoti River estuary, northeast Brazil. Plots of Partial Least Square for variables: Soil vs. Fauna (c), Flora vs. Fauna (d), Environmental (Soil + Flora) vs. Fauna (e), and Soil vs. Flora (f).

tree density and dominance, and with soil softness variables (Pen, $\mathrm{OM}, \mathrm{Cl}+\mathrm{Sl})$. The variables tree density and 'brachyuran diversity' were more closely related to the RL area, and tree dominance, and soft soils to the $\mathrm{R}$ area. The association with some soil and fauna variables was positive for AL area, but this progressively decreased in the RLA, A, and C areas. RLA area was positively associated to seedling density, in contrast to A and $\mathrm{R}$ areas. The A area was the most positively associated with salinity, while the $\mathrm{L}$ area, close to the origin center of the biplot, showed no tendency of association with any variable (Fig. 2a). The PCs 1 and 3 (47.10\%) showed a tendency similar to that observed for PCs 1 and 2, except for the $\mathrm{AL}$ area, more positively associated with the abundance of ocypodoids and sediments less penetrable than R (Table 3, 
Table 3. Principal Component Analysis results of abiotic soil variables and biotic variables (Flora and assemblages of brachyuran crabs and gastropods; see text for variables description) in different mono, multispecific and control mangrove tree areas in the Pacoti River estuary, Northeast Brazil. PC, Principal Component; Var (\%), proportion of variance; CumVar (\%), cumulative variance of data.

\begin{tabular}{|c|c|c|c|}
\hline \multicolumn{4}{|c|}{ Proportion of Variance } \\
\hline & $\mathrm{PC} 1$ & PC2 & $\mathrm{PC} 3$ \\
\hline Eigenvalue & 4.19 & 2.03 & 1.93 \\
\hline $\operatorname{Var}(\%)$ & 32.22 & 23.32 & 14.88 \\
\hline CumVar (\%) & 32.22 & 55.54 & 70.42 \\
\hline \multicolumn{4}{|c|}{ Loadings } \\
\hline Pen & 0.267 & 0.347 & 0.061 \\
\hline OM & 0.306 & 0.319 & -0.177 \\
\hline $\mathrm{S}$ & -0.240 & 0.282 & 0.432 \\
\hline $\mathrm{Cl}+\mathrm{S} 1$ & 0.321 & 0.271 & -0.292 \\
\hline TDiv & 0.101 & -0.429 & 0.318 \\
\hline Dom & 0.235 & 0.378 & 0.256 \\
\hline SeeDens & 0.151 & -0.313 & 0.120 \\
\hline $\mathrm{TM} / \mathrm{J}$ & -0.010 & 0.191 & -0.065 \\
\hline TDens & 0.379 & -0.210 & 0.179 \\
\hline Gon & 0.384 & -0.135 & 0.283 \\
\hline UBurr & 0.294 & -0.026 & -0.272 \\
\hline CrbRch & 0.451 & -0.096 & 0.154 \\
\hline SnDiv & -0.076 & 0.302 & 0.546 \\
\hline \multicolumn{4}{|c|}{ Scores } \\
\hline A & -2.493 & 2.129 & 1.134 \\
\hline L & 0.490 & -0.307 & -0.112 \\
\hline $\mathrm{R}$ & 1.272 & 1.966 & 0.859 \\
\hline RL & 2.974 & -0.437 & -0.462 \\
\hline $\mathrm{AL}$ & 0.913 & 0.518 & -1.427 \\
\hline RLA & -0.369 & -2.871 & 1.918 \\
\hline $\mathrm{C}$ & -2.706 & -0.999 & -1.909 \\
\hline
\end{tabular}

Fig. 2b). The RLA area was positively associated with snail diversity and salinity.

The investigation of residuals of each PLS regression showed no outliers, so it was possible to use data from all surveyed areas, even those that appeared very distinct in exploratory PCA. The PLS regression for Soil vs. Fauna (Table 4a, Fig. 2c) showed that the first two PLS factors made up $78.51 \%$ of the variation of the Fauna data. 'Brachyuran diversity' variables showed higher weights for the first factor and snail diversity for the second factor. Hence, respective VIPs indicate that Goniopsis abundance and crab richness were highly relevant and ocypodoid abundance was relevant in their contributions to community assemblage. 'Brachyuran diversity' variables were positively correlated to all soil variables except salinity. For the PLS of Flora vs. Fauna (Table 4b, Fig. 2d), the first two factors accounted for $72.14 \%$. Weights

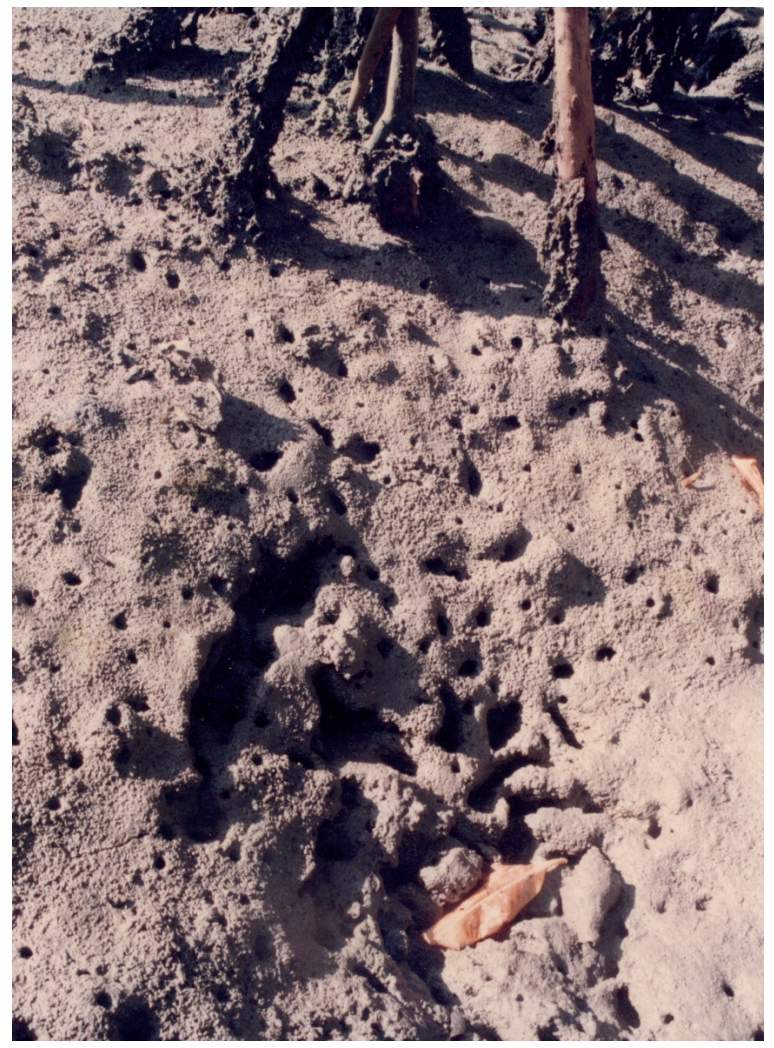

Figure 3. Common multiple entrances of a communal burrows system, close to Rhizophora roots. Individual burrows of fiddler crabs are seen around the entrances of the system.

in the first factor were relevant to the variables Goniopsis abundance and crab richness, while for snail diversity showed relevance for factor 2. The respective VIPs of the variables revealed a highly relevant contribution of Goniopsis abundance and crab richness in community assemblage, while ocypodoid abundance had no relevant contribution. Goniopsis abundance and crab richness showed positive correlations with all variables of the Flora matrix, mainly seedling and tree density, but a negative correlation with open space between trees $(\mathrm{TM} / \mathrm{J})$. Despite snail diversity had a negative correlation with most variables, showed a high relevant contribution in tree dominance and density of flora and in soil variables, being positively correlated to salinity and penetrability, and less associated to clay + silt content comparing to other fauna variables.

In the PLS regression for Soil vs. Flora (Table 4c, Fig. 2f), both PLS factors made up 51.79\% of the Flora data variation. Tree diversity and mainly dominance are high relevant, and seedling and tree density relevant contributors in community assemblage, while forest maturity (TM/J) did not. Higher weights in factor 1 were registered for the variable tree dominance, and in factor 2 for seedling density. Tree dominance and density showed a positive correlation with soil variables except salinity, contrary to seedling density and tree diversity, negatively correlated to soil variables. When exploring the environmental variables (i.e., Soil and Flora together) vs Fauna (Table 4d, Fig. 2e), both PLS factors made up $78.56 \%$ 
Table 4. Coefficients, Projection and Variable Importance (VIP), weights of variables and proportion of variance of the two axes (1 and 2) generated by Partial Least Square (PLS) analysis investigating correlations between Soil vs. Fauna (a), Flora vs. Fauna (b), Soil vs. Flora (c), and Environmental variables vs. Fauna (d). See text for variables description. The VIPs, Weights and variances in Table d) were placed below to improve visualization. VIP, Variable Importance Projection at each axis; PLSw, Weights of variables at each axis; PLSv, Proportion of variance at each axis. Values in black bold are variables of highly relevant contribution; gray bold values are for variables of relevant contribution.

\begin{tabular}{|c|c|c|c|c|c|c|c|c|c|c|}
\hline \multicolumn{11}{|c|}{ a) Soil vs. Fauna } \\
\hline \multirow[t]{2}{*}{ Variables } & \multicolumn{4}{|c|}{ Coefficients } & \multicolumn{2}{|c|}{ VIP } & \multicolumn{2}{|c|}{ Weights } & \multicolumn{2}{|c|}{ Variance } \\
\hline & Pen & $\mathrm{OM}$ & $\mathrm{S}$ & $\mathrm{Cl}+\mathrm{Sl}$ & VIP1 & VIP2 & PLSw1 & PLSw2 & PLSv1 & PLSv2 \\
\hline Gon & 0.17 & 0.13 & -0.20 & 0.15 & 1.04 & 0.78 & 0.52 & -0.05 & $51.56 \%$ & $26.95 \%$ \\
\hline UBurr & 0.23 & 0.16 & -0.08 & 0.15 & 0.99 & 0.79 & 0.49 & 0.21 & \multirow{2}{*}{\multicolumn{2}{|c|}{$\begin{array}{c}\text { (Total variance } \\
78.51 \% \text { ) }\end{array}$}} \\
\hline CrbRch & 0.28 & 0.20 & -0.12 & 0.19 & 1.24 & 0.98 & 0.62 & 0.23 & & \\
\hline SnDiv & 0.36 & 0.16 & 0.79 & -0.03 & 0.59 & 1.34 & -0.29 & 0.94 & & \\
\hline
\end{tabular}

b) Flora vs. Fauna

\begin{tabular}{lccccccccccc}
\hline \multirow{2}{*}{ Variables } & \multicolumn{4}{c}{ Coefficients } & \multicolumn{4}{c}{ VIP } & \multicolumn{2}{c}{ Weights } & \multicolumn{2}{c}{ Variance } \\
\cline { 2 - 11 } & TDiv & Dom & SeeDens & TM/J & TDens & VIP1 & VIP2 & PLSw1 & PLSw2 & PLSv1 & PLSv2 \\
\hline Gon & 0.41 & 0.35 & 1.62 & -0.27 & 10.41 & $\mathbf{1 . 2 7}$ & $\mathbf{1 . 0 2}$ & 0.64 & 0.00 & $51.59 \%$ & $20.55 \%$ \\
UBurr & 0.00 & 0.00 & 0.00 & 0.00 & 0.01 & 0.67 & 0.76 & 0.34 & -0.45 & (Total variance \\
CrbRch & 0.03 & 0.01 & 0.13 & -0.01 & 0.63 & $\mathbf{1 . 3 8}$ & $\mathbf{1 . 1 1}$ & 0.69 & 0.11 & $72.14 \%)$ \\
SnDiv & -0.28 & 0.47 & -2.29 & -0.43 & 0.30 & 0.17 & $\mathbf{1 . 0 7}$ & -0.08 & -0.89 & \\
\hline
\end{tabular}

c) Soil vs. Flora

\begin{tabular}{lcccccccccc}
\hline \multirow{2}{*}{ Variables } & \multicolumn{3}{c}{ Coefficients } & \multicolumn{3}{c}{ VIP } & \multicolumn{2}{c}{ Weights } & \multicolumn{2}{c}{ Variance } \\
\cline { 2 - 10 } & Pen & OM & S & Cl+S1 & VIP1 & VIP2 & PLSw1 & PLSw2 & PLSv1 & PLSv2 \\
\hline TDiv & -0.31 & $-0,13$ & -0.16 & -0.13 & $\mathbf{1 . 0 5}$ & $\mathbf{1 . 0 1}$ & -0.47 & -0.38 & $29.36 \%$ & $22.42 \%$ \\
Dom & 0.49 & 0.50 & 0.25 & 0.42 & $\mathbf{1 . 7 2}$ & $\mathbf{1 . 4 9}$ & 0.77 & 0.12 & \\
SeeDens & -0.20 & $-0,53$ & -0.10 & -0.42 & 0.74 & $\mathbf{0 . 8 5}$ & -0.33 & 0.50 & (Total variance \\
TM/J & 0.12 & 0.05 & 0.06 & 0.05 & 0.43 & 0.41 & 0.19 & 0.15 & $51.78 \%)$ \\
TDens & 0.11 & 0.56 & 0.05 & 0.43 & 0.43 & $\mathbf{0 . 9 1}$ & 0.19 & -0.74 & \\
\hline
\end{tabular}

d) Environmental variables vs. Fauna

\begin{tabular}{|c|c|c|c|c|c|c|c|c|c|}
\hline \multirow[t]{2}{*}{ Variables } & \multicolumn{9}{|c|}{ Coefficients } \\
\hline & Pen & $\mathrm{OM}$ & $\mathrm{S}$ & $\mathrm{Cl}+\mathrm{Sl}$ & TDiv & Dom & SeeDens & $\mathrm{TM} / \mathrm{J}$ & TDens \\
\hline Gon & 0.20 & 0.15 & -0.19 & 0.17 & 0.13 & 0.13 & 0.15 & -0.11 & 0.33 \\
\hline UBurr & 0.20 & 0.14 & -0.03 & 0.12 & 0.09 & 0.15 & 0.05 & -0.11 & 0.25 \\
\hline CrbRch & 0.24 & 0.18 & -0.19 & 0.19 & 0.15 & 0.16 & 0.16 & -0.13 & 0.38 \\
\hline \multirow[t]{3}{*}{ SnDiv } & 0.33 & 0.16 & 0.80 & -0.03 & -0.07 & 0.44 & -0.04 & -0.22 & -0.01 \\
\hline & \multicolumn{2}{|c|}{ VIP } & \multicolumn{2}{|c|}{ Weights } & \multicolumn{2}{|c|}{ Variance } & & & \\
\hline & VIP1 & VIP2 & PLSw1 & PLSw2 & PLSv1 & PLSv2 & & & \\
\hline Gon & 1.18 & 0.93 & 0.59 & 0.05 & $51.85 \%$ & $26.71 \%$ & & & \\
\hline UBurr & 0.84 & 0.69 & 0.42 & 0.17 & \multicolumn{2}{|c|}{ (Total variance } & & & \\
\hline CrbRch & 1.33 & 1.06 & 0.78 & 0.09 & \multicolumn{2}{|c|}{$78.56 \%)$} & & & \\
\hline SnDiv & 0.33 & 1.22 & -0.16 & 0.98 & & & & & \\
\hline
\end{tabular}


of the Fauna data variation, exhibiting similar trends of associations, such as relevance of Goniopsis density and crab richness in community assemblage.

\section{Discussion}

\section{Macrofauna and relationship with soil/flora variables}

Five grapsoids, six ocypodoids, and one xanthoid crab inhabit the surveyed intertidal mangrove areas of Pacoti River. Most grapsoids are forest dwellers due to their herbivorous/ omnivorous feeding habits (Macintosh 1988, Burggren and McMahon 1988, Lee 1998, Cannicci et al, 2008). Similarly to the herbivore ocypodoid Ucides cordatus, some fiddler crabs species prefer habitat under canopy, like Minuca thayeri and Leptuca cumulanta, while others live in open habitats (Ferreira 1998, Bezerra et al. 2006). Most crabs are rarely seen outside burrows, except tree climbers such as Goniopsis, post-juvenile stages of Aratus pisonii, and surface deposit feeders like fiddler crabs.

In newly formed sedimentary areas with soft i.e., more penetrable sediment, we found juvenile to adult stages of most grapsoids, plus Leptuca cumulanta, Minuca thayeri and Ucides (Ocypodoidea), while ocypodoids Minuca rapax and Leptuca leptodactyla colonized coarser and/or lower organic sandy areas like the control, as found in other estuaries at regional level (Rebelo-Mochel 1997, Ferreira and Sankarankutty 2002). Sediment features (penetrability, grain composition, organic matter content), in great part determined by frequency and reach of tidal coverage, are primary determinants of brachyuran diversity, since most species use burrows for protection and vital activities from the early stages (Frusher et al. 1994, Skov and Hartnoll 2002, Morrissey et al. 2003, Koch et al. 2005, Bezerra et al. 2006, Kristensen 2008, Moh et al. 2015).

The strong positive association between plant density and dominance, 'brachyuran diversity', sediment softness and organic content with Rhizophora (alone as well together with Laguncularia), confirms that red mangrove presence is strongly associated to increase in these variables (Cintrón and Schaeffer-Novelli 1983, Ferreira 1998, Ferreira et al. 2015). This association decreases in the absence of Rhizophora, being lower in Avicennia-Laguncularia and the lowest in monospecific Avicennia and the control area. Monospecific Avicennia is related to higher salinity, being dominant in upper littoral and hypersaline soils (Alleman and Hester 2011, Pascoalini et al. 2014), and high salinity limited brachyuran diversity in spite a relative content of sediment organic matter in Pacoti River. Brachyuran diversity is negatively related to high salinity, especially if exposed to dryness (Burggren and McMahon 1988).

Higher plant density and its architecture offer protection against predators and can determine the brachyuran community that assembles, since vegetated areas tend to have more grapsoids (Ferreira and Sankarankutty 2002, Ashton et al. 2003b, Wang et al. 2014, Van Nedervelde et al. 2015). Strong correlations found in our data suggest tree density can explain density of Goniopsis and crab richness in the young successional stages of mangrove development. We found the density of Goniopsis strongly correlated to tree density rather than to tree diversity and dominance, since this species finds more shelter, abundant vegetal matter and small prey (fiddler crabs, minor grapsoids and other invertebrates) between the roots (Burggren and McMahon 1988, Lima-Gomes et al. 2011). Hence, our data support that density of Rhizophora and their roots, i.e., their structural heterogeneity, is a stronger factor in promoting brachyuran diversity than tree richness. This ecological condition was also found in Malaysian mangrove (Ashton et al. 2003b), and makes sense since grapsoids, for example, use the vertical dimension from tunnel systems (via roots and trunks) to canopy, extending space use of brachyurans above and belowground in the Neotropics.

The studied areas showed low gastropod abundance and diversity, this latter correlated with salinity, and partially correlated with penetrability, tree density and dominance. Indeed, Melampus coffeus is by far the most present at soft sediments (mainly at Rhizophora), as Neritina virginea, while the others were found mostly on roots and trunks. Interestingly, the positive correlation of snail diversity with salinity, was due by the massive presence of Littoraria flava (a high desiccation resistant but not exclusive mangrove inhabitant species like L. angulifera - Moutinho and Alves-Costa 2000, Melo et al. 2012) and L. angulifera fixed to branches of Avicennia forests, with predominate in sandier soils, pushing down correlation of snails with fine sediment. Observations suggest a low significant effect of snails in mangrove community shaping at Pacoti River, considering yet that Melampus coffeus has a low effect on detritus consumption in this river when compared with other Neotropical mangroves (Tavares et al. (2011). We did not find gastropods in crab burrows.

As expected, soil variables softness and organic content were related to tree maturity and Rhizophora dominance (Cintrón and Schaeffer-Novelli 1983, Zamprogno et al. 2016), but not to seedling density and tree diversity, which are most likely regulated by propagule consumption by crabs, since grapsoids (mainly Goniopsis) can consume far more propagules of Laguncularia and Avicennia than of Rhizophora (Smith III 1987b, Ferreira et al. 2013).

\section{Interrelation of biotic and abiotic factors in community assemblage}

Community structure in mangroves, as in most tropical forests, is regulated by environmental heterogeneity and species interactions (Diamond 1975, Terborgh et al. 1996, Clark et al. 1998, Potts et al. 2004, Tews et al. 2004, Vermeiren and Sheaves 2015). Grapsoid and ocypodoid crabs abundance and richness, and also Rhizophora trees presence, revealed high relevance in the assemblage of the studied community, due to their ecosystem engineering capacity (Jones et al. 1994, Cuddington et al. 2007).

More penetrable sediments with higher organic matter content favor the establishment of a higher diversity of brachyurans in Pacoti River. Established brachyuran species 
can mediate forest composition by high differential propagule consumption and/or burial (Ferreira et al. 2013, 2019). When forest composition is dominated by Rhizophora, prop root structure allows construction of rich multi-specific brachyuran interconnected systems of burrows, proper of Neotropical mangroves. These complex systems (Warner 1969, Abele 1976, Ferreira and Sankarankutty 2002) are far more developed among Rhizophora prop roots since dense subsurface cord roots of Laguncularia and Avicennia stands impair their existence (Ferreira 1998).

We observed at Pacoti that opportunist massive recruitments of Laguncularia seedlings can overcome initial Rhizophora growing if not decimated by herbivore grapsoids, and eventually dominate intertidal areas (Soares 1999, Ferreira et al. 2015) trapping detritus and more crab species. Hence, our evidence indicates that disturbed mangroves
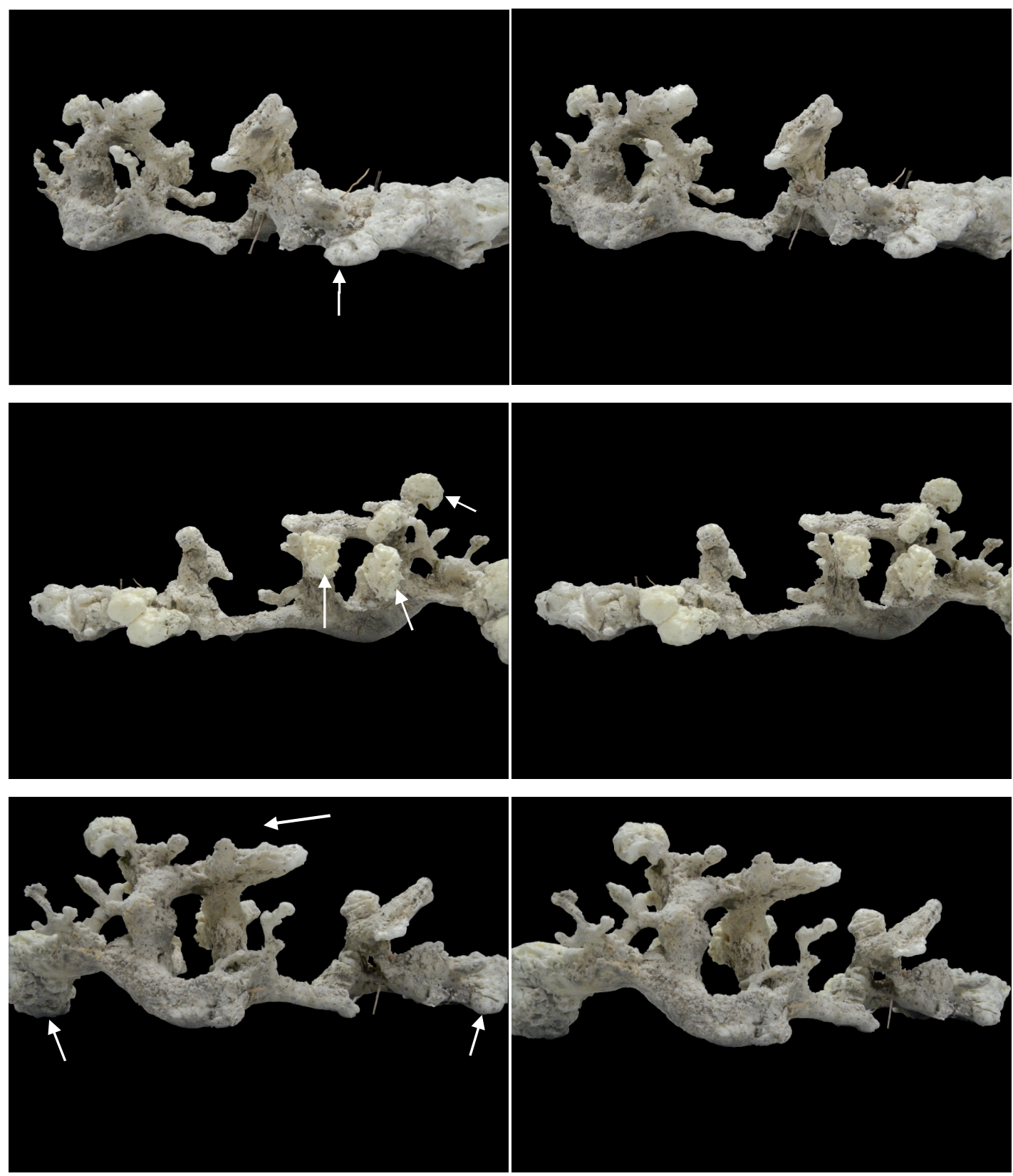

Figure 4. Stereoscopic images (from 3 different angles) of the cast of part of a communal burrow system around the roots in a Rhizophora stand. Position of cast corresponds approximately to the natural layout. Burrow openings are shown by globular expansion that material suffered on the outside (setae) while remaining rugged parts of the cast are the walls of interconnected tunnels and chambers. Some fine tertiary roots can be seen embedded in the cast. The upper portion showed in the lower image setae shows several entrances together. Since the system was in a sloping area, some entrances are on top and others lateral. In some portions of the system, the foam stopped (solidified) before reaching their whole tunnels extension, so some inferior tunnels may be longer. Approximate dimensions: max. vertical axis $25 \mathrm{~cm} /$ max. horizontal axis $60 \mathrm{~cm}$. 
with predominance of Laguncularia could be transient reservoirs of crab assemblage in new estuarine forest patches, such as might occur in the case of impact over low intertidal Rhizophora forests by sea level rise. Colpo et al. (2011) found a similar rich brachyuran assemblage in Laguncularia dominated forests in southeast Brazil, but did not report the existence of crab communal burrows, and it would be interesting to know how brachyurans distribute spatially their burrows in such forests to establish comparisons. Even when Laguncularia forest can persist in different substrates, muddier or sandier, our observations show that the associated crab richness tends to decrease with root development (Ferreira 1998).

Goniopsis is a dominant species in Neotropical mangroves, and other crabs use burrows to protect themselves from their predatory habits (McNaughton and Wolf 1970, Ferreira et al. 2013, Cannicci et al. 2018). This crab is observed gnawing on the cortexes of red mangrove roots, which induces their sprouting (Calderon and Echeverri 1997). In addition, together with other smaller grapsoids like Sesarma curacaoense, S. rectum, and Pachygrapsus gracilis, Goniopsis can promote the predominance of Rhizophora through preference in consumption of Laguncularia and Avicennia spp. propagules (Souza and Sampaio 2011, Ferreira et al. 2013). Thus, evidence indicates a specific relationship between grapsoid diversity and red mangroves presence, as observed for sesarmid crabs elsewhere (Bosire et al. 2005). Indeed, while several sesarmids occupy specific soil-tree interface habitats in similar Indo-West Pacific mangroves (Dahdouh-Guebas et al. 1997, Vannini et al. 1997, Ashton et al. 2003a), Goniopsis is a key non-sesarmid species ( $\mathrm{Ng}$ et al. 2008) which occupies an ample niche dimension of this habitat (from deep soil to canopy), being significant on mangrove ecosystem engineering (Jones et al. 1994, Ferreira et al. 2019).

\section{Communal burrows structure}

The association in systems of interconnected burrows is a key feature found in Neotropical brachyuran assemblage (Fig. 4), and most littoral grapsoids and xanthoids and the Ocypodid Ucides cordatus inhabit these systems in their life cycle (Warner 1969, Abele 1976, Ferreira and Sankarankutty 2002, Ferreira et al. 2015). These anastomosed burrows are more developed in the sediment among Rhizophora roots (Ferreira 1998). We already collected crabs excavating tunnels of these structures elsewhere (Ferreira 1998, Ferreira and Sankarankutty 2002), but the obtained cast here gives an insight of their real structure. Roots can be a highly significant variable operating over the complexity of crab burrows, but can impair burrow depth if they are very dense (Ferreira 1998, Wang et al. 2014). Rhizophora prop roots ramify and secondary roots diverge underground, potentially reaching $1 \mathrm{~m}$ (Gill and Tomlinson 1977), and are among these roots and among neighbor roots where crabs find space to construct burrows, sometimes relatively deep.

We found multiple surface openings (Fig. 3) of several diameters that lead to a large main chamber with interconnecting tunnels of different diameters at several levels (Fig. 4).
Adults of Ucides are most likely responsible for the construction of larger tunnels (Warner 1969, Branco 1991, Ventura et al. 2008). Some paths seem to be only enlarged gaps between oyster clumps and secondary roots. Although some small tunnels were preserved in the cast, we failed to capture species responsible for these minor interconnected paths. Ucides juveniles and xanthoids Eurytium limosum and Panopeus lacustris construct horizontal burrows and are probably responsible for some medium and minor tunnels (Atkinson and Eastman 2015). Although all grapsoids, when threatened, seek immediate protection in the closer entrance, no observational data exist on digging behavior of these crabs in such communal systems, while some crabs of this Superfamily can construct complex tunnels elsewhere (Macintosh 1988, Morrisey et al. 1999, Thongtham and Kristensen 2003, Katrak et al. 2008, Wang et al. 2014, Atkinson and Eastman 2015). Leptuca cumulanta and Minuca thayeri are in general not part of interconnected systems, since they construct individual and simple burrows (Atkinson and Eastman 2015). Some tunnels could also be primarily constructed by some Alpheidae (e.g., Alpheus estuariensis) or Hippolytidae (e.g., Merguia rhizophorae) shrimps and further enlarged by crab transit.

Ovigerous females and sub-adult stages of Ucides, Panopeus lacustris, Pachygrapsus gracilis, Sesarma curacaoense and S. rectum have been collected from these systems elsewhere (Ferreira 1998). Some of these crab species probably start their benthonic life directly by settling and developing in these systems by avoiding unprotected bare areas, as in the case of Ucides (Butman 1987, Schmidt and Diele 2009), but still we ignore how different stages of this and other species are distributed inside them. We can hypothesize that the existence of several species in the systems may be consequence of one or several factors such as overcrowding and/or high predation risk in the surface, high species richness, resource(s) abundance, or low competition. These and other ecological interrelationships among species as well the real extension of burrow systems remain to be studied.

Communal burrows existence and architecture are emergent features that result from the interaction of the spatial niche dimension of brachyurans and trees, i.e., from their engineering capacity. Whereas multispecific communal systems have been found elsewhere in the Neotropics, they have not been cited for Indo-West Pacific (IWP) mangroves, where several sesarmids compete on the sediment surface (Smith et al. 1987a, Robertson and Daniel 1989, Vannini et al. 1997, Ashton et al. 2003a). It would be interesting to investigate the architecture of brachyuran burrows in these IWP Rhizophora forests and if they differ from other tree specific stands. Complex burrows are probably limited by roots in high multispecific tree stands of this realm (Ricklefs and Latham 1993, Leung 2015a).

Acknowledgments. We would like to thank CAPES (Coordenação de Aperfeiçoamento de Pessoal de Nível Superior/MEC, Brazil) for providing post-doctoral (AC Ferreira) and doctoral grants (CERD Alencar). We also thank H. Mathews-Cascon for identifying the gastropods, G. 
B. Colares for the Laboratory tests, and R. X. França, Y. B. Lima, H. P. do Nascimento, R. P. Barbosa, Y. D. dos Santos and R. Kobayashi for their valuable help in the field.

\section{References}

Abdi, H. 2007. Partial Least Square Regression PLS-Regression. In N. Salkind (Ed.), Encyclopedia of Measurement and Statistic. Sage, Thousand Oaks. pp. 1-13.

Abele, L.G. 1976. Comparative species composition and relative abundance of decapod crustaceans in marine habitats of Panama. Mar. Biol. 38:263-278.

Alleman, L.K., and M.W. Hester. 2011. Refinement of the fundamental niche of black mangrove (Avicennia germinans) seedlings in Louisiana: Applications for restoration. Wetlands Ecol. Manage. 19:47-60.

Alongi, D.M. 2009. Paradigm shifts in mangrove biology. In: G.M.E Perillo, E. Wolanski, D.R. Cahoon and M.M. Brinson (eds.), Coastal Wetlands, an Integrated Ecosystem Approach. Elsevier, London, pp. 615-640.

Alongi, D.M. 2014. Carbon cycling and storage in mangrove forests Annu. Rev. Mar. Sci. 6:195-219.

Aschenbroich, A., E. Michaud, T. Stieglitz, F. Fromard, A. Gardel, M. Tavares and G. Thouzeau. 2016. Brachyuran crab community structure and associated sediment reworking activities in pioneer and young mangroves of French Guiana, South America. Estuar. Coast. Shelf Sci. 182:60-71.

Ashton, E.C., P J. Hogarth and D.J. Macintosh. 2003a. A comparison of brachyuran crab community structure at four mangrove locations under different management systems along the Melaka Straits-Andaman Sea coast of Malaysia and Thailand. Estuaries 26:1461-1471.

Ashton, E.C., D.J. Macintosh and P.J. Hogarth. 2003b. A baseline study of the diversity and community ecology of crab and molluscan macrofauna in the Sematan mangrove forest, Sarawak, Malaysia. J. Trop. Ecol. 19:127-142.

Atkinson, R.J.A. and L.B. Eastman. 2015. Burrow dwelling in Crustacea. In: M. Thiel and L. Watling (eds.), The Natural History of the Crustacea, Vol 2: Lifestyles and Feeding Biology. Oxford University Press, New York. pp. 78-117.

Barreto, H.B.F., W.O. Santos and C.M. da Cruz. 2012. Analysis of the distribution of mean annual rainfall in the state of Ceará. Revista Verde de Agroecologia e Desenvolvimento Sustentável 7:122-128.

Bezerra, L.E.A., C.B. Dias, G.X. Santana and H. Matthews-Cascon 2006. Spatial distribution of fiddler crabs (genus $U c a$ ) in a tropical mangrove of northeast Brazil. Sci. Mar. 70:759-766.

Bosire, J.O., J.G. Kairo, J. Kazungu, N. Koedam and F. DahdouhGuebas. 2005. Predation on propagules regulates regeneration in a high-density reforested mangrove plantation. Mar. Ecol. Prog. Ser. 299:149-155.

Branco, J.O. 1991. Aspectos ecológicos dos Brachyura (Crustacea: Decapoda) no mangezal de Itacorubi, SC-Brasil. Rev. Bras. Zool. 7:165-179.

Brower, J. and J.H. Zar. 1984. Field and Laboratory Methods for General Ecology. 2nd ed. WCB Publishers, Iowa.

Burggren, W. and B. McMahon. 1988. Biology of the Land Crabs. Cambridge University Press, Cambridge.

Butman, C.A. 1987. Larval settlement of soft-sediment invertebrates: the spatial scale of pattern explained by active habitat selection and the emerging role of hydrodynamical processes. Oceanogr. Mar. Biol. Annu. Rev. 25:113-165.

Calderon, D.G. and B.R. Echeverri. 1997. Obtaining Rhizophora mangle seedlings by stimulation of adventitious roots using an air-layering technique. In: B. Kjerfve (ed.), Mangrove Ecosystem Studies in Latin America and Africa. UNESCO, Paris. pp. 98 107.

Cannicci, S., B. Burrows, S. Fratini, T.J. Smith III, J. Offenberg and F. Dahdouh-Guebas. 2008. Faunal impact on vegetation structure and ecosystem function in mangrove forests: a review. Aquat. Bot. 89:186-200.

Cannicci, S., M. Fusi, F. Cipó, F. Dahdouh-Guebas and S. Fratini. 2018. Interference competition as a key determinant for spatial distribution of mangrove crabs. BMC Ecology 18:1-12.

Carmona-Suárez, C. 2011. Present status of Cardisoma guanhumi Latreille, 1828 (Crustacea: Brachyura: Gecarcinidae) populations in Venezuela. Interciencia 36:908-913.

Chapman, M.G. and T.J. Tolhurst. 2004. The relationship between invertebrate assemblages and bio-dependent properties of sediment in urbanized temperate mangrove forests. J. Exp. Mar. Biol. Ecol. 304:51-73.

Chen, G., Y. Yong and C. Lu. 2007. Changes of macro-benthic faunal community with stand age of rehabilitated Kandelia candel mangrove in Jiulongjiang Estuary, China. Ecol. Eng. 31:215-224.

Cintrón, G. and Y. Schaeffer-Novelli. 1983. Introducción a la ecología del Manglar. UNESCO, Montevideo.

Clark, D.B., D.A. Clarke and J.M. Read. 1998. Edaphic mesoscale and the distribution of tree species in a neotropical rain forest. $J$. Ecol. 86:101-112.

Clarke, P.J. and W.G. Allaway. 1993. The regeneration niche of the grey mangrove (Avicennia marina): effects of salinity, light and sediment factors on establishment, growth and survival in the field. Oecologia 93:548-556.

Cleveland, W.S. 1993. Visualizing Data. Hobart Press, NJ.

Colares, G.B. and V.M.M. Melo. 2013. Relating microbial community structure and environmental variables in mangrove sediments inside Rhizophora mangle L. habitats. Appl. Soil Ecol. 64: 171-177.

Colpo, K.D., M.M. Chacur, F.J. Guimarães and M.L. NegreirosFransozo. 2011. Subtropical Brazilian mangroves as a refuge of crab (Decapoda: Brachyura) diversity. Biodivers. Conserv. 20: 3239-3250.

Cuddington, K., J.E. Byers, W.G. Wilson and A. Hastings. 2007. Ecosystem engineers, from Plants to Protists. Elsevier, Oxford.

Dahdouh-Guebas, F., M. Verneirt, J.F. Tack and N. Koedam. 1997. Food preferences of Neosarmatium meinerti de Man (Decapoda: Sesarminae) and its possible effect on the regeneration of mangroves. Hydrobiologia 347:83-89.

Diamond, J.M. 1975. Assembly of species communities. In: M. Cody and J.M. Diamond (eds.), Ecology and Evolution of Communities. Harvard University Press, Cambridge. pp. 342-444.

Donato, D.C., J.B. Kauffman, D. Murdiyarso, S. Kurnianto, M. Stidham and M. Kanninen. 2011. Mangroves among the most carbon-rich forests in the tropics. Nat. Geosci. 4:293-297.

Feng, J., J. Guo, Q. Huang, J. Jiang, G. Huang, Z. Yang and G. Lin. 2014. Changes in the community structure and diet of benthic macrofauna in invasive Spartina alterniflora wetlands following restoration with native mangroves. Wetlands 34:673-683.

Ferreira, A.C. 1998. Composição de Crustacea (Decapoda) dos manguezais do Município de Macau/RN. MSc Dissertation, Federal University of Rio Grande do Norte (UFRN), Natal, Brazil. 
Ferreira, A.C. and C. Sankarankutty. 2002. Estuarine Carcinofuna (Decapoda) of Rio Grande do Norte, Brazil. Nauplius 2:121129.

Ferreira, A.C. and L.D. Lacerda. 2016. Degradation and conservation of Brazilian mangroves, status and perspectives. Ocean. Coast. Manag. 125:38-46.

Ferreira, A.C., G. Ganade, F.A.M. Freire and J.L. Attayde. 2013. Propagule predation in a Neotropical mangrove: the role of the grapsid crab Goniopsis cruentata. Hydrobiologia 707:135-146.

Ferreira, A.C., G. Ganade and J.L Attayde. 2015. Restoration versus natural regeneration in a neotropical mangrove: Effects on plant biomass and crab communities. Ocean Coast. Manage. 110:38-45.

Ferreira, A.C., L.E.A. Bezerra and H. Mathews-Cascon. 2019. Aboveground stock in a restored Neotropical mangrove: Influence of management and brachyuran crab assemblage. Wetlands Ecol. Manage. 27:223-242.

Fiuza, A.B.J.Q., L.G.O. Le Hugeur and B.J. Queiroz. 2010. Análise ambiental do baixo curso do rio Pacoti - Ceará. Arq. Ciên. Mar. 43:18-29.

Frusher, S., R.L. Giddins and T.J. Smith III. 1994. Distribution and abundance of grapsid crabs (Grapsidae) in a mangrove estuary: Effects of sediment characteristics, salinity tolerances, and osmoregulatory ability. Estuaries 17:647-654.

Fukami, T. and D.A. Wardle. 2005. Long-term ecological dynamics: reciprocal insights from natural and anthropogenic gradients. Proceedings of the Royal Society B 272:2105-2115.

Gill A.M. and P.B. Tomlinson. 1977. Studies on the growth of red mangrove (Rhizophora mangle L.) 4. The adult root system. Biotropica 9:145-155.

Goes, P., J.O. Branco, M.A.A. Pinheiro, E. Barbieri, D. Costa and L.L. Fernandes. 2010. Bioecology of the Uçá-crab, Ucides cordatus (Linnaeus, 1763) in Vitória Bay, Espírito Santo State, Brazil. Braz. J. Ocean. 58:153-163.

Gotelli, N.J. and A.M. Ellison. 2004. A primer of Ecological Statistics. Sinauer Ass. Inc., Massachussetts.

Graham, A. 1995. Diversification of Gulf/Caribbean mangrove communities through Cenozoic time. Biotropica 27:20-27.

Hammer, Ø., D.A.T. Harper and P.D. Ryan. 2001. Past: Paleontological statistics software package for education and data analysis. Palaeontol. Electronica 4:1-9.

Höskuldsson, A. 1988. PLS Regression Methods. J. Chemometr. 2: 211-228.

Jolliffe, I.T. 2002. Principal Component Analysis. 2nd ed. Springer, New York.

Jones, C.G., J.H. Lawton and M. Schachak. 1994. Organisms as ecosystem engineers. Oikos 69:373-386.

Katrak, G., S. Dittmann and L. Seuront. 2008. Spatial variation in burrow morphology of the mud shore crab Helograpsus haswellianus (Brachyura, Grapsidae) in South Australian saltmarshes. Mar Freshw. Res. 59:902-911.

Kauffman, J.B., A.F. Bernardino, T.O. Ferreira, N.W. Bolton, L.E.O. Gomes and G.N. Nobrega. 2018. Shrimp ponds lead to massive loss of soil carbon and greenhouse gas emissions in northeastern Brazilian mangroves. Ecol. Evol. 8:5530-5540.

Koch, V. and M. Wolff. 2002. Energy budget and ecological role of mangrove epibenthos in the Caeté estuary, North Brazil. Mar. Ecol. Prog. Ser. 228:119-130.

Koch, V., M. Wolff and K. Diele. 2005. Comparative population dynamics of four fiddler crabs (Ocypodidae, genus $U c a$ ) from a North Brazilian mangrove ecosystem. Mar. Ecol. Prog. Ser. 291: 177-188.
Krauss, K.W., C.E. Lovelock, K.L. McKee, L. López-Hoffman, S.M.L. Ewe and W.P. Sousa. 2008. Environmental drivers in mangrove establishment and early development: A review. Aquat. Bot. 89:105-127.

Kristensen, E. and D.M. Alongi. 2006. Control by fiddler crabs (Uca vocans) and plant roots (Avicennia marina) on carbon, iron, and sulfur biogeochemistry in mangrove sediment. Limnol. Oceanogr. 51:1557-1571.

Kristensen, E. and J.E. Kostka. 2005. Macrofaunal burrows and irrigation in marine sediment: Microbiological and biogeochemical interactions. In: E. Kristensen, R.R. Haese and J.E. Kostka (eds.), Interactions Between Macro- and Microorganisms in Marine Sediments. American Geophysical Union, Washington. pp. $125-157$.

Kristensen, E. 2008. Mangrove crabs as ecosystem engineers; with emphasis on sediment processes. J. Sea Res. 59:30-43.

Lacerda, L.D. (ed.) 2002. Mangrove Ecosystems: Function and Management. Springer Verlag, Berlin.

Lacerda, L.D. and R.V. Marins. 2002. River damming and changes in mangrove distribution. Glomis / ISME Electronic Journal 2:1-4.

Lacerda, L.D., V. Ittekkot and S.R. Patchineelam. 1995. Biogeochemistry of mangrove soil organic matter: a comparison between Rhizophora and Avicennia soils in southeastern Brazil. Estuar. Coast. Shelf Sci. 40:713-720.

Lacerda, L.D., M.O.T. Menezes and M.M. Molisani. 2007. Changes in mangrove extension at the Pacoti River estuary, CE, NE Brazil due to regional environmental changes between 1958 and 2004. Biota Neotrop. 7:67-72.

Lee, S.Y. 1998. Ecological role of grapsid crabs in mangrove ecosystems: A review. Mar. Fresh. Res. 49:335-343.

Lee, S.Y. 1999. Tropical mangrove ecology: physical and biotic factors influencing ecosystem structure and function. Aust. J. Ecol. 24:355-366.

Leung, J.Y.S. 2015a. Habitat heterogeneity affects ecological functions of macrobenthic communities in a mangrove: Implication for the impact of restoration and afforestation. Glob. Ecol. Conserv. 4:423-433.

Leung, J.Y.S. 2015b. Habitat heterogeneity determining the macrobenthic infaunal community in a mangrove swamp in South China: Implication for plantation and plant invasion. J. Coast. Res. 31:624-633.

Lima-Gomes, R.C., V.J. Cobo and A. Fransozo. 2011. Feeding behaviour and ecosystem role of the red mangrove crab Goniopsis cruentata (Latreille, 1803) (Decapoda, Grapsoidea) in a subtropical estuary on the Brazilian coast. Crustaceana 84:735-747.

Macintosh, D.J. 1988. The ecology and physiology of decapods of mangrove swamps. Symp. Zool. Soc. London 59:315-341.

Macintosh, D.J., E.C. Ashton and S. Havanon. 2002. Mangrove rehabilitation and intertidal biodiversity: A study in the Ranong Mangrove Ecosystem, Thailand. Estuar. Coast. Shelf Sci. 55: 331-345.

McNaughton, S.J. and L.L. Wolf. 1970. Dominance and the niche in ecological systems. Science 167:131-139.

Minchinton, T.E. 2001. Canopy and substratum heterogeneity influence recruitment of the mangrove Avicennia marina. J. Ecol. 89: 888-902.

Moh, H.H., V.C. Chong and A. Sasekumar. 2015. Distribution and burrow morphology of three sympatric species of Thalassina mud lobsters in relation to environmental parameters on a Malayan mangrove shore. J. Sea Res. 95:75-83.

Morrisey, D.J., T.H. DeWitt, D.S. Roper and R.B. Williamson. 1999. Variation in the depth and morphology of burrows of the mud 
crab Helice crassa among different types of intertidal sediment in New Zealand. Mar. Ecol. Prog. Ser. 182:231-242.

Morrisey, D.J., G.A. Skilleter, J.I. Ellis, B.R. Burns, C.E. Kempa and K. Burt. 2003. Differences in benthic fauna and sediment among mangrove (Avicennia marina var. australasica) stands of different ages in New Zealand. Estuar. Coast. Shelf Sci. 56:581-592.

Nash, M.S., D.J. Chaloud and R.D. Lopez. 2005. Applications of Canonical Correlation and Partial Least Squares Analyses in Landscape Ecology. U.S. Environmental Protection Agency, Las Vegas.

Ng, P.K.L., D. Guinot and P.J.F. Davie. 2008. Systema Brachyurorum: part I. An annotated list of Extant Brachyuran crabs of the world. Raffles Bull. Zool. 17:1-286.

Pascoalini, S.S., D.M.S. Lopes, A.R. Falqueto and M.M.P. Tognella. 2014. Abordagem ecofisiológica dos manguezais: uma revisão. Biotemas 27:1-11.

Pickett, S.T.A. 1989. Space-for-time substitution as an alternative to long-term studies. In: G.E. Likens (Ed.), Long-term Studies in Ecology: Approaches and Alternatives. Springer-Verlag, New York. pp. 110-135.

Potts, M.D., S.J. Davies, W.H. Bossert, S. Tan and M.N. Nur Supardi. 2004. Habitat heterogeneity and niche structure of trees in two tropical rain forests. Oecologia 139:446-453.

Proffitt, C.E. and D.J. Devlin. 2005. Grazing by the intertidal gastropod Melampus coffeus greatly increases mangrove leaf litter degradation rates. Mar. Ecol. Prog. Ser. 296:209-218.

Quintero-Torres, E., N. Chacón and B. López-Sánchez. 2018. The ecosystem engineering role of the Neotropical crab Cardisoma guanhumi on mangrove soil properties. Wetlands Ecol. Manage. 26:993-1000.

Rebelo-Mochel, F. 1997. Mangroves on São Luiz Island, Maranhão, Brazil. In: B. Kjerfve (ed.), Mangrove Ecosystem Studies in Latin America and Africa. UNESCO, Paris. pp. 145-154.

R Development Core Team. 2012. R: A language and environment for statistical computing. R Foundation for Statistical Computing, Vienna, Austria. ISBN 3-900051-07-0. http://www.R-project. org

Ricklefs, R.E. and R.E. Latham. 1993. Global patterns of diversity in mangrove floras. In: R.E. Ricklefs and D. Schluter (eds.) Species Diversity in Ecological Communities: Historical and Geographical Perspectives. University of Chicago Press, Chicago. pp. 215-229.

Robertson, A.I. and P.A. Daniel. 1989. Decomposition and the annual flux of detritus from fallen timber in tropical mangrove forests. Limnol. Oceanogr. 34:640-646.

Sanchez, G. and L. Trinchera. 2012. Plspm: Partial Least Squares Data Analysis Methods. R package version 0.2-2. http:// CRAN.R-project.org/package $=$ plspm

Schaeffer-Novelli, Y. and G. Cintrón. 1986. Guia para estudo de áreas de manguezal; estrutura, função eflora. Caribbean Ecological Research, São Paulo.

Schmidt, A.J. and K. Diele. 2009. First field record of mangrove crab Ucides cordatus (Crustacea: Decapoda: Ucididae) recruits coinhabiting burrows of conspecific crabs. Zoologia 26:792-794.

Schulte, E.E. and B.G. Hopkins. 1996. Estimation of sediment organic matter by weight loss-on ignition. In: F.R. Magdoff, M.A. Tabatabai and E.A. Hanlon (Eds.), Sediment Organic Matter: Analysis and Interpretation. Sediment Science Society of America, Madison. pp. 21-31.

Shih, H.T., P.K.L. Ng, P.J.F. Davie, C.D. Schubart, M. Türkay, R. Naderloo, D. Jones and M.Y. Liu. 2016. Systematics of the family Ocypodidae Rafinesque, 1815 (Crustacea: Brachyura), based on phylogenetic relationships, with a reorganization of subfamily rankings and a review of the taxonomic status of $U c a$ Leach, 1814, sensu lato and its subgenera. Raffles Bull. Zool. 64:139175.

Skov, M.W. and R.G. Hartnoll. 2002. Paradoxical selective feeding on a low-nutrient diet: why do mangrove crabs eat leaves? Oecologia 131:1-7.

Smith III, T.J. 1987a. Effects of seed predators and light level on the distribution of Avicennia marina (Forsk.) Vierh. in tropical, tidal forests. Est. Coast. Shelf Sci. 25:43-51.

Smith III, T.J. $1987 \mathrm{~b}$. Seed predation in relation to tree dominance and distribution in mangrove forests. Ecology 68:266-273.

Smith III, T.J., K.G. Boto, S.D. Frusher and R.L. Giddins. 1991. Keystone species and mangrove forest dynamics: the influence of burrowing by crabs on soil nutrient status and forest productivity. Est. Coast. Shelf Sci. 33:419-432.

Smith III, T.J., H.T. Chan, C.C. McIvor and M.B. Robblee. 1989 Comparisons of seed predation in tropical tidal forests from three continents. Ecology 70:146-151.

Soares, M.L.G. 1999. Estrutura vegetal e grau de perturbação dos manguezais da Lagoa da Tijuca, Rio de Janeiro, RJ, Brasil. Rev. Bras. Biol. 59:503-515.

Sobek, S., Tranvik, L. J., Cole, J. J. 2005. Temperature independence of carbon dioxide supersaturation in global lakes. Global Biogeochem. Cycles 19:1-10

Souza, M.M.A. and E.V.S.B Sampaio. 2011. Predation on propagules and seedlings in mature and regenerating mangroves in the coast of Ceará, Brazil. Hydrobiologia 661:179-186.

Tavares, D.S., R.C. Maia and C.A. Rocha-Barreira. 2011 Contribuição de Melampus coffeus (Gastropoda, Ellobiidae) na degradação da serapilheira do médio estuário do rio Pacoti, Ceará, Brasil. Iheringia 101:56-60.

Terborgh, J., R.B. Foster and P.V. Nuñez. 1996. Tropical tree communities: a test of the nonequilibrium hypothesis. Ecology 77 : 561-567.

Tews, J., U. Brose, V. Grimm, K. Tielbörger, M.C. Wichmann, M. Schwager and F. Jeltsch. 2004. Animal species diversity driven by habitat heterogeneity/diversity: the importance of keystone structures. J. Biogeogr. 31:79-92.

Thom, B.G. 1967. Mangrove ecology and deltaic geomorphology: Tabasco, Mexico. J. Ecol. 55:301-343.

Thongtham, N. and E. Kristensen. 2003. Physical chemical characteristics of mangrove crab Neoepisesarma versicolor burrows in the Bangrong mangrove forest, Phuket, Thailand; with emphasis on behavioral response to changing environmental conditions. Vie Milieu 53:141-151.

Vale, V.F., S.A.S.N. Moraes, V.L.G. Brito, C.E.R.D. Alencar and F.A.M. Freire. 2017. Shell use by sympatric hermit crab species in a seasonally open coastal lagoon in Northeastern Brazil. Mar. Ecol. e12451:1-14.

Valiela, I., J.L. Bowen, J.K. York. 2001. Mangrove forests: one of the World's threatened major tropical environments. BioScience 51:807-815.

Van Nedervelde, F., S. Cannicci, N. Koedam, J. Bosire and F. Dahdouh-Guebas. 2015. What regulates crab predation on mangrove propagules? Acta Oecol. 63:63-70.

Vannini, M., A. Oluoch, R.K. Ruwa. 1997. Tree climbing decapods of Kenyan mangroves. In: B. Kjerfve (ed.), Mangrove Ecosystem studies in Latin America and Africa. UNESCO, Paris. pp. 325338.

Ventura, R., U.A.Y. Silva, G. Perbiche-Neves, A. Ostrensky, W.A.P. Boeger and M.R. Pie. 2008. Duration of the pre-settlement 
period of the mangrove crab Ucides cordatus (Decapoda: Ocypodidae) under laboratory conditions. Braz. Arch. Biol. Technol. 5:957-962.

Vermeiren, P. and M. Sheaves. 2014. Predictable habitat associations of five intertidal crab species across estuaries. Est. Coast. Shelf Sci. 149:133-142.

Wang, M., X. Gao and W. Wang. 2014. Differences in burrow morphology of crabs between Spartina alterniflora marsh and mangrove habitats. Ecol. Eng. 69:213-219.

Warner, G.F. 1969. The occurrence and distribution of crabs in a Jamaican mangrove swamp. J. Anim. Ecol. 38:379-389.

Warren, J.H. and A.J. Underwood. 1986. Effects of burrowing crabs on the topography of mangrove swamps in New South Wales. $J$. Exp. Mar. Biol. Ecol. 102:223-235.

Wold, S. 1995. PLS for multivariate linear modeling. In: H. Van de Waterbeemd (ed.), Chemometric Methods in Molecular Design, Methods and Principles in Medicinal Chemistry. Verlag-Chemie, Germany. pp. 195-218.

Worthington, T. and M. Spalding. 2018. Mangrove Restoration Potential: A global map highlighting a critical opportunity.
IUCN. pp. 1-19. https://www.iucn.org/sites/dev/files/content/ documents/mangrove-tnc-report-final.31.10.lowspreads.pdf

Woodroffe, C.D. 1983. Development of mangrove forests from a geological perspective. In: H.J. Teas (ed.), Biology and Ecology of Mangroves. W. Junk Publishers, The Hague. pp. 1-17.

Zamprogno, G.C., M.M.P. Tognella, V.S. Quaresma, M.B. Costa, S.S. Pascoalini and G.F. Couto. 2016. The structural heterogeneity of an urbanised mangrove forest area in southeastern Brazil: Influence of environmental factors and anthropogenic stressors. Braz. J. Oceanogr. 64:157-172.

Zenone, A., F. Badalamenti, V.M. Giacalone, L. Musco, C. Pipitone, T.V. Fernández, G. D’Anna. 2016. Substrate preference and settlement behaviour of the megalopa of the invasive crab Percnon gibbesi (Decapoda, Percnidae) in the Mediterranean Sea. Helgol. Mar. Res. 70:1-7.

Received December 8, 2018 Revised July 16, November 10, 2019 Accepted November 13, 2019 